\title{
Phytochemical and Antioxidant Dynamics of the Soursop Fruit (Annona muricata L.) in response to Colletotrichum spp.
}

\author{
Alejandro Rubio-Melgarejo, ${ }^{1,2}$ Rosendo Balois-Morales, ${ }^{1,2}$ \\ Yolotzin Apatzingan Palomino-Hermosillo, ${ }^{2}$ Graciela Guadalupe López-Guzmán, ${ }^{1,3}$ \\ José Carmen Ramírez-Ramírez, ${ }^{4}$ Edwin Cervantes-García, ${ }^{2,5}$ \\ Brandon Javier Villalobos-Rosario, ${ }^{2,5}$ and Pedro Ulises Bautista-Rosales $\mathbb{D I}^{1,2}$ \\ ${ }^{1}$ Programa de Doctorado en Ciencias Biológico Agropecuarias, Universidad Autónoma de Nayarit, \\ Carretera Tepic-Compostela km. 9, C.P. 63780, Xalisco, Nayarit, Mexico \\ ${ }^{2}$ Unidad de Tecnología de Alimentos, Secretaría de Investigación y Posgrado, Universidad Autónoma de Nayarit, \\ Ciudad de la Cultura S/N, Colonia Centro, C.P. 63000, Tepic, Nayarit, Mexico \\ ${ }^{3}$ Unidad Académica de Agricultura, Universidad Autónoma de Nayarit, Carretera Tepic-Compostela km. 9, C.P. 63780, Xalisco, \\ Nayarit, Mexico \\ ${ }^{4}$ Unidad Académica de Medicina Veterinaria y Zootecnia, Universidad Autónoma de Nayarit, \\ Carretera Compostela-Chapalilla km 3.5, C.P. 63700, Compostela, Nayarit, Mexico \\ ${ }^{5}$ Instituto Tecnológico de Acapulco, Av. Tecnológico S/N, Crucero de Cayaco, C.P. 39905, Acapulco, Guerrero, Mexico
}

Correspondence should be addressed to Pedro Ulises Bautista-Rosales; u_bautista@hotmail.com

Received 20 January 2020; Revised 25 August 2020; Accepted 5 September 2020; Published 22 September 2020

Academic Editor: Encarna Aguayo

Copyright (c) 2020 Alejandro Rubio-Melgarejo et al. This is an open access article distributed under the Creative Commons Attribution License, which permits unrestricted use, distribution, and reproduction in any medium, provided the original work is properly cited.

\begin{abstract}
This work evaluates the effect of the pathogens Colletotrichum siamense and C. gloeosporioides on the response of soursop fruits. The bioactive compounds (total phenols, flavonoids, anthraquinones, coumarins, steroids, terpenoids, alkaloids, and saponins)

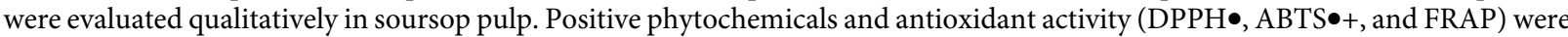
quantified at day zero, one, three, and five. Fruits treated with C. gloeosporioides showed higher disease severity $(P<0.05)$. Early fruit response (day one) was observed with both pathogens, increased the concentration of saponins and repressed the production of quercetin 3-O-glucoside $(P<0.05)$. Likewise, $C$. siamense decreased total soluble phenols and flavonoids and increased antiradical activity DPPH•. Besides, C. gloeosporioides decreased the levels of kaempferol 3-O-rutinoside and ferulic acid $(P<0.05)$. Regarding the late response (day three), both pathogens decreased the concentration of saponins and increased flavonoids and phytosterols $(P<0.05)$. Nevertheless, $C$. siamense increased the levels of total soluble phenols, $\mathrm{p}$-coumaric acid, kaempferol, and antiradical activity FRAP $(P<0.05)$. Also, $C$. gloeosporioides repressed the production of quercetin 3-O-glucoside at day five $(P<0.05)$. Soursop fruits had a response to the attack of Colletotrichum during ripening at physicochemical and oxidative levels, which is associated with the production of compounds related to the development inhibition of pathogens. Even so, soursop fruits showed higher susceptibility to C. gloeosporioides and higher sensitivity to the attack of C. siamense.
\end{abstract}

\section{Introduction}

The soursop (Annona muricata L.) is classified as multiple fruit, and its consumption is mainly fresh. The highest production of this fruit is located in Venezuela, Brazil, Colombia, and Mexico. Mexico is the largest producer and consumer of soursop $[1,2]$. Soursop fruit has excellent marketing potential, since it has a good taste for the consumer [3]. In Mexico, Nayarit is the leading producer of this fruit with a production of $21,810.86 \mathrm{t}$ in 2017 [2].

The rapid softening during postharvest storage is one of the most critical problems that avoid the commercialization 
of this fruit. The most used method to preserve soursop and prevent its softening is refrigeration, with which the shelf life has been extended up to 8 days [4]. Moreover, other factors have also reduced the marketing to international markets such as irregular production, low fruit quality, and pathogen attack [5]. In this regard, fruits are attacked by the fungi Colletotrichum spp., which produce a disease called anthracnose [6]. Álvarez et al. [7] identified several species of Colletotrichum, such as C. theobromicola, C. tropicale, C. siamense, and C. gloeosporioides, among others in different tissues of soursop by PCR using the sequences of the ITS regions.

On the other hand, the plants have generated defense mechanisms that allow them to tolerate the damages caused by pathogens [8]. However, when the organisms exceeded the structural defense mechanisms of the plant, a second defense barrier associated with the translation of the pathogen-induced signals are activated in messages that trigger defense strategies specific to plant immunity [9]. One of these mechanisms is the induction of systemic defense that includes the production of secondary metabolites such as phenols, flavonoids, tannins, saponins, anthocyanins, acetogenins, lignins, proteinase inhibitors, lectins, defensins, volatile, phytoalexins (including isoflavonoids), terpenoids, and alkaloids [10], which have an essential role in biotic interactions such as chemical defense against herbivores and pathogens [11]. Nevertheless, few reports exist that evaluate the secondary metabolisms as an anthracnose resistance defense mechanism in the soursop fruit-pathogen interaction.

Due to the abovementioned, the objective of the present work was to evaluate the pathogenic damage and the effect of the pathogens $C$. siamense and C. gloeosporioides on the response of soursop fruits in the phytochemical content and antioxidant activity.

\section{Materials and Methods}

2.1. Experimental Site and Plant Material. Soursop fruits (Annona muricata L.) were harvested at physiological maturity from a commercial orchard located in the Ejido Puerta de la Lima, Compostela, Nayarit, Mexico $\left(21^{\circ} 05^{\prime} \mathrm{N} ;-105^{\circ}\right.$ $11^{\prime} \mathrm{W} ; 30$ m.a.s.l.). Soursop fruits are multiple fruits, which are derived from several separate individual flowers whose fertilized ovaries are fused to join a single structure. Each of the fruits is derived from a berry. The soursop fruits were ovoid. They are covered with scattered spine-like structures. The pulp of the soursop fruits is soft, white, fibrous, and fleshy [12]. Fruits without mechanical, physical, or/and phytopathological damages were selected. After, the fruits were disinfected by immersion in sodium hypochlorite at $1.5 \%$ for two minutes and then rinsed with sterile distilled water [13].

2.2. Microorganisms. Colletotrichum gloeosporioides and C. siamense strains were used for this investigation. These pathogens were previously sequenced and analyzed by BLAST in the NCBI database (National Center for
Biotechnology Information), showing a high identity (99\%) with C. gloeosporioides (KP238317.1) and C. siamense (KR445677.1).

2.3. Fruit Inoculation. Soursop fruits were inoculated by immersion for one min in a spore suspension $\left(1 \times 10^{5 \circ} \mathrm{esp}\right.$./ $\mathrm{mL}$ ) of the fungus C. gloeosporioides or C. siamense [14]. The fruits were stored at $28 \pm 22^{\circ} \mathrm{C}$ with a relative humidity of $95 \%$. Fruits were further evaluated at $0,1,3$, and 5 days of storage.

2.4. Infection Severity Assessment. The percentage of pathological damage in the fruit cuticle was used to determine the severity of the infection on day 3 , that is, when the fruits reached the maturity of consumption.

\subsection{Phytochemical Analysis}

2.5.1. Sample Preparation. One gram of soursop pulp was homogenized with distilled water using an Ultraturrax (T8 IKA $^{\circledR}$ Staufen, Germany) and then centrifuged (Z326 K Hermle, Wehingen, Germany) at $10410 \mathrm{~g}$ for $15 \mathrm{~min}$ at $4^{\circ} \mathrm{C}$. Finally, the supernatant was recovered [15].

2.5.2. Qualitative Analysis of Phytochemical Compounds. To determine the presence of total soluble phenols, flavonoids, anthraquinones, coumarins, steroids, terpenoids, alkaloids, and saponins in soursop treatments, the standard methods described by Sofowara [16], Harborne [17], and Evans [18] were used. The results were expressed with the presence $(+)$ or absence $(-)$ of the phytochemical compound evaluated. These techniques are described below.

2.6. Phenols and Tannins. Three hundred microliters of the extract were added to a reaction tube; afterward, a few drops of ferric chloride $\left(\mathrm{FeCl}_{3}\right)$ at $10 \%$ were added. The appearance of a blue or green precipitate indicated the presence of phenols and tannins [18].

2.7. Flavonoids. Three hundred microliters of the extract were added to a reaction tube; then, $1 \mathrm{~mL}$ of $10 \%$ ammonia (as $\mathrm{NH}_{4} \mathrm{OH}$ ) and $1 \mathrm{~mL}$ of concentrated $\mathrm{H}_{2} \mathrm{SO}_{4}$ were added. The disappearance of the yellow color indicated the presence of flavonoids [18].

2.8. Coumarins. Three hundred microliters of the extract was added to a reaction tube. Next, a filter paper strip previously soaked in an alkaline solution of $\mathrm{NaOH}(0.06 \mathrm{~g} /$ $\mathrm{mL}$ ) was placed inside the tube without touching the extract. Then, the tube was capped and heated to vapor evolution. The presence of fluorescent spots indicated that the sample was positive [18].

2.9. Anthraquinones. One milliliter of benzene, $1 \mathrm{~mL}$ of $10 \%$ ammonia (as $\mathrm{NH}_{4} \mathrm{OH}$ ), and $300 \mu \mathrm{L}$ of extract were added in 
a reaction tube. The test is positive if a pink, red, or violet color appears in the low phase ammonia [16].

2.10. Steroids and Terpenoids. Three hundred microliters of extract was placed in a tube; next, $1 \mathrm{~mL}$ of chloroform was added. After, the tubes were cooled on ice. Then, a few drops of sulfuric acid were added and evaluated. The generation of reddish-brown precipitate at the tube bottom indicated the presence of steroids. The formation of a reddish-brown phase at the top indicated the presence of terpenoids [17].

2.11. Alkaloids. Three hundred microliters of extract were placed in a reaction tube; next, $300 \mu \mathrm{L}$ of $2 \mathrm{~N}$ hydrochloric acid $(\mathrm{HCl}) 2 \mathrm{~N}$ and $300 \mu \mathrm{L}$ of Mayer's reagent were added. The presence of a pale precipitate indicated the presence of the alkaloids [16].

2.12. Saponins. Three hundred microliters of extract were added to a reaction tube; next, $2 \mathrm{~mL}$ of distilled water was added. Then, the mix water-extract was vigorously stirred for $10 \mathrm{~s}$. The test was positive if the foam is persistent and stable [16].

2.13. Quantitative Analysis of Phytochemical Compounds. The content of total soluble phenols, flavonoids, steroids, and saponins was determined according to the procedures described next.

2.14. Total Soluble Phenols. The content of total soluble phenols was determined with the method proposed by Singleton et al. [19]. The determinations were performed at $760 \mathrm{~nm}$ in a spectrophotometer (BioTek Synergy HT, USA), and a calibration curve from 0 to $400 \mathrm{mg} \cdot \mathrm{L}^{-1}$ with gallic acid was carried out. The results were expressed in mg equivalents of gallic acid per $100 \mathrm{~g}$ of fresh weight (mg EAG/100 g FW).

2.15. Total Flavonoids. The total flavonoid content was determined by adding $1.4 \mathrm{~mL}$ of deionized water and $0.5 \mathrm{~mL}$ of the flavonoid reagent to $0.1 \mathrm{~mL}$ of the extract. Later, it was allowed to stand for $30 \mathrm{~min}$ in the dark, and then, absorbance was measured at $430 \mathrm{~nm}$ in a spectrophotometer (BioTek Synergy HT, USA). A calibration curve with routine in a concentration range of $0-10 \mathrm{~g} \cdot \mathrm{L}^{-1}$ was performed. The total flavonoid content was expressed as $\mathrm{mg}$ routine equivalents per $100 \mathrm{~g}$ of fresh weight (mg RE/100 $\mathrm{g} \mathrm{FW).} \mathrm{The} \mathrm{flavonoid}$ reagent was prepared as follows: first, $70 \mathrm{~mL}$ of methanol, $25 \mathrm{~mL}$ of distilled water, and $5 \mathrm{~mL}$ of acetic acid were mixed. Next, $133 \mathrm{mg}$ of aluminum trichloride and $400 \mathrm{mg}$ of sodium acetate were added and mixed [20].

2.16. Total Steroids. The total steroid content was determined using the Lieberman-Buchard method [21] at a wavelength of $550 \mathrm{~nm}$ (BioTek Synergy HT, USA). The total steroid content was quantified through a calibration curve from 0 to $1000 \mathrm{mg} \cdot \mathrm{L}^{-1}$ using cholesterol as standard. The results were expressed in $\mathrm{mg}$ equivalents of cholesterol per $100 \mathrm{~g}$ of fresh weight (mg EC/100 g FW).

2.17. Total Saponins. The total content of saponins was determined according to the indirect method described by Soto et al. [22]. This method is based on the determination of reducing sugars by the 3,5 dinitrosalicylic acid (DNS) method [23]. A calibration curve was developed with triterpene saponin of Quillaja saponaria (20-35\% saponin) with concentration ranges from $0 \mathrm{~g} \cdot \mathrm{L}^{-1}$ to $10 \mathrm{~g} \cdot \mathrm{L}^{-1}$. The results were expressed in $\mathrm{mg}$ equivalent to saponin of Quillaja saponaria on $100 \mathrm{~g}$ of fresh weight (mg ESQS/100 g FW).

2.18. Determination of Antioxidant Capacity by the DPPH Method. To determine antioxidant capacity by the DPPH method, the protocol proposed by Brand-Williams et al. [24] was used. The change in absorbance at $517 \mathrm{~nm}$ was measured in a spectrophotometer (BioTek Synergy HT, USA). Antioxidant activity was determined using a calibration curve with ascorbic acid with concentration ranges from 0 to $100 \mathrm{mg} \cdot \mathrm{L}^{-1}$. The results were expressed in $\mathrm{mg}$ equivalents of ascorbic acid on $100 \mathrm{~g}$ of fresh weight (mg EAA/100 g FW).

2.19. Determination of Antioxidant Capacity by the ABTS Technique. The determination of antioxidant capacity by the ABTS method was performed using the method described by Re et al. [25]. The absorbance was measured in a spectrophotometer (BioTek Synergy HT, USA) at $734 \mathrm{~nm}$. Antioxidant activity was determined using a calibration curve with ascorbic acid with values from 0 to $150 \mathrm{mg} \cdot \mathrm{L}^{-1}$. The results were expressed in mg equivalent of ascorbic acid on $100 \mathrm{~g}$ of fresh weight (mg EAA/100 $\mathrm{g} \mathrm{FW).}$

2.20. Antioxidant Capacity of Iron Reduction (FRAP). The antioxidant capacity of iron reduction (FRAP) was determined by the method described by Yen and Chen [26]. Absorbance was measured at $700 \mathrm{~nm}$ using a spectrophotometer (BioTek Synergy HT, USA). The reducing activity was determined with a calibration curve using ascorbic acid concentrations from 0 to $30 \mathrm{mg} \cdot \mathrm{L}^{-1}$. The results were expressed in mg equivalents ascorbic acid on $100 \mathrm{~g}$ of fresh weight (mg EAA/100 g FW).

2.21. Analysis and Identification of Phenolic Soluble Compounds by UPLC-ESI-QTOFMS ${ }^{E}$. Phytochemical profile was analyzed using an ultra-performance liquid chromatography system (UPLC), Acquity UPLC ${ }^{\text {тм }} \mathrm{H}$-Class (Waters, Manchester, Reino Unido), coupled to a mass spectrometer (MS QTof) with an atmospheric pressure electrospray ionization (ESI) interface (Vion, Waters Co, MA, USA). The column used was an Acquity BEH C18 $(100 \times 2.1 \mathrm{~mm}, 1.7 \mathrm{um})$ at $35^{\circ} \mathrm{C}$. The elution gradient was performed with a binary system consisting of (A) $0.1 \%$ formic acid in water and (B) $0.1 \%$ formic acid in acetonitrile. The following gradient was 
applied at a flow rate of $0.4 \mathrm{~mL} / \mathrm{min}: 0 \mathrm{~min}, 5 \% \mathrm{~B}$ and $22 \mathrm{~min}$, $95 \% \mathrm{~B}$, held for $5 \mathrm{~min}$, followed by a rebalance step for $3 \mathrm{~min}$. The injection volume was $2 \mu \mathrm{L}$, and the sample temperature was set at $10^{\circ} \mathrm{C}$ [27]. The conditions of the mass spectrometer were as follows: the temperature of the source was adjusted to $120^{\circ} \mathrm{C}$, and nitrogen was used as the desolvation gas $(800 \mathrm{~L} / \mathrm{h})$ at a temperature of $450^{\circ} \mathrm{C}$. The sampling cone and capillary voltages were $40 \mathrm{~V}$ and $3.5 \mathrm{kV}$, respectively. Data acquisition was performed using the high definition MSE negative ionization mode with a mass range of 50-2000 Da. Leucine-enkephalin $(50 \mathrm{pg} / \mathrm{mL})$ at $10 \mathrm{~mL} / \mathrm{min}$ was used for mass correction. Peak identification was carried out by identifying the exact mass of the pseudomolecular ion (confirmation of elemental composition with $<10 \mathrm{ppm}$ mass error), analysis of the fragmentation pattern, and isotopic distribution of the pseudomolecular ion. Data acquisition was performed with the UNIFI Scientific Information System (Waters Co).

2.22. Statistical Analysis. A completely randomized design was used for statistical analysis of the severity of the infection. Data were analyzed using Analysis of Variance (ANOVA) with a 5\% significance level. The comparison of means was carried out using the Tukey test. The experimental unit was one fruit with six replicates on different fruits.

A completely randomized block design was used to analyze the rest of the variables measured. The blocks were the days of storage. All experiments were analyzed by Analysis of Variance (ANOVA) with a 5\% significance level. The comparison of means was carried out using the LSD test when ANOVA showed significant differences. The experimental unit was one fruit with six replicates on different fruits.

\section{Results and Discussion}

3.1. Severity of the Pathogenicity. Figure 1 shows the damage of soursop fruits in different treatments (control, C. siamense, and C. gloeosporioides) stored for three days after inoculation at $28 \pm 2{ }^{\circ} \mathrm{C}$. The fruit damage indicates the virulence of the pathogens and the sensitivity from the fruits to strains evaluated. The control and treated fruits with $C$. siamense showed no significant statistical differences in the pathogenesis $(P<0.05)$, as it is observed in Figure 2. Arauz [28] mentions that Colletotrichum spp. cause latent infections, and once the phytopathogenic fungi found the right conditions, the disease is generated.

The control and treated fruits with C. gloeosoporioides showed significant statistical differences in the pathogenesis $(P<0.05)$. Fruits treated with $C$. gloeosporioides showed greater severity of the disease. However, treated fruits with C. siamense showed no significant statistical differences in the severity of the disease with the fruits treated with C. gloeosporioides or with the control fruits $(P>0.05)$ (Figure 2).

C. gloeosporioides is considered the principal causative agent of anthracnose in soursop [29], while C. siamense has been described recently for this fruit [7]. Possibly, this is because $C$. gloeosporioides has developed strategies to avoid the defense mechanisms of the fruit. In contrast, $C$. siamense has not yet fully developed these abilities, which may cause soursop fruits to be more sensitive to the presence of this fungus, triggering biochemical responses and the production of different types of metabolites, as it is shown in later results.

\subsection{Phytochemical Evaluation of Soursop Fruits}

\subsubsection{Qualitative Analysis of Phytochemicals Compounds.}

The phytochemical profile results were positive for the presence of total soluble phenols, saponins, flavonoids, and phytosterols in the three evaluated treatments (control fruits, fruits inoculated with C. gloeosporioides, and fruits inoculated with C. siamense) (Table 1). The presence of phenols, saponins, flavonoids, and phytosterols has been reported in ethanolic and aqueous extracts of soursop fruits [30]. These compounds have been previously reported by their antibacterial and antifungal activities [31]. The quantitative analysis of the compounds is shown in the following sections.

\subsubsection{Quantitative Analysis of Phytochemicals Compounds}

(1) Total Soluble Phenols. Total soluble phenols decreased in the first days of the experiment in the three treatments. ANOVA showed significant differences $(P<0.05)$ for the fruits inoculated with $C$. siamense on day 1 (77.10 mg EAG/ $100 \mathrm{~g}$ FW) compared with the fruits inoculated with C. gloeosporioides ( $98.62 \mathrm{mg} \mathrm{EAG} / 100 \mathrm{~g} \mathrm{FW}$ ) and control (101.35 mg EAG/100 g FW) (Figure 3(a)). Therefore, we observed an early response of the fruits to the presence of this fungus.

Pérez-Márquez et al. [32] reported that when the tissue cell is healthy and intact, polyphenol oxidase (PPO) enzyme and its substrates (phenols) are found in separate compartments (chloroplasts and vacuoles, respectively). Nonetheless, when the cell is infected, the PPO enzyme and the substrates come into contact, and an oxidation reaction occurs, generating the formation of quinones, which explains the decrease in the phenolic compounds of the fruits treated with $C$. siamense.

On the other hand, the fruits treated with $C$. siamense showed a significant increase $(P<0.05)$ on day $3(118.08 \mathrm{mg}$ EAG/100 g FW) in comparison to C. gloeosporioides and the control (93.55 and $91.03 \mathrm{mg}$ EAG/100 g FW, respectively) that did not show significant differences between them $(P>0.05)$ indicating a late response of the fruits to the presence of $C$. siamense (Figure 3(a)).

Subsequently, an increase in the concentration of total phenols for all treatments on day five was recorded. However, the fruits with the presence of pathogens showed a significantly higher concentration $(P<0.05)$ of phenols with values of $164.68 \mathrm{mg} \mathrm{EAG} / 100 \mathrm{~g} \mathrm{FW}$ for $C$. siamense and $159.49 \mathrm{mg}$ EAG/100 g FW for C. gloeosporioides compared to the control $134.36 \mathrm{mg}$ EAG/100 $\mathrm{g} \mathrm{FW}$. That indicates that the 

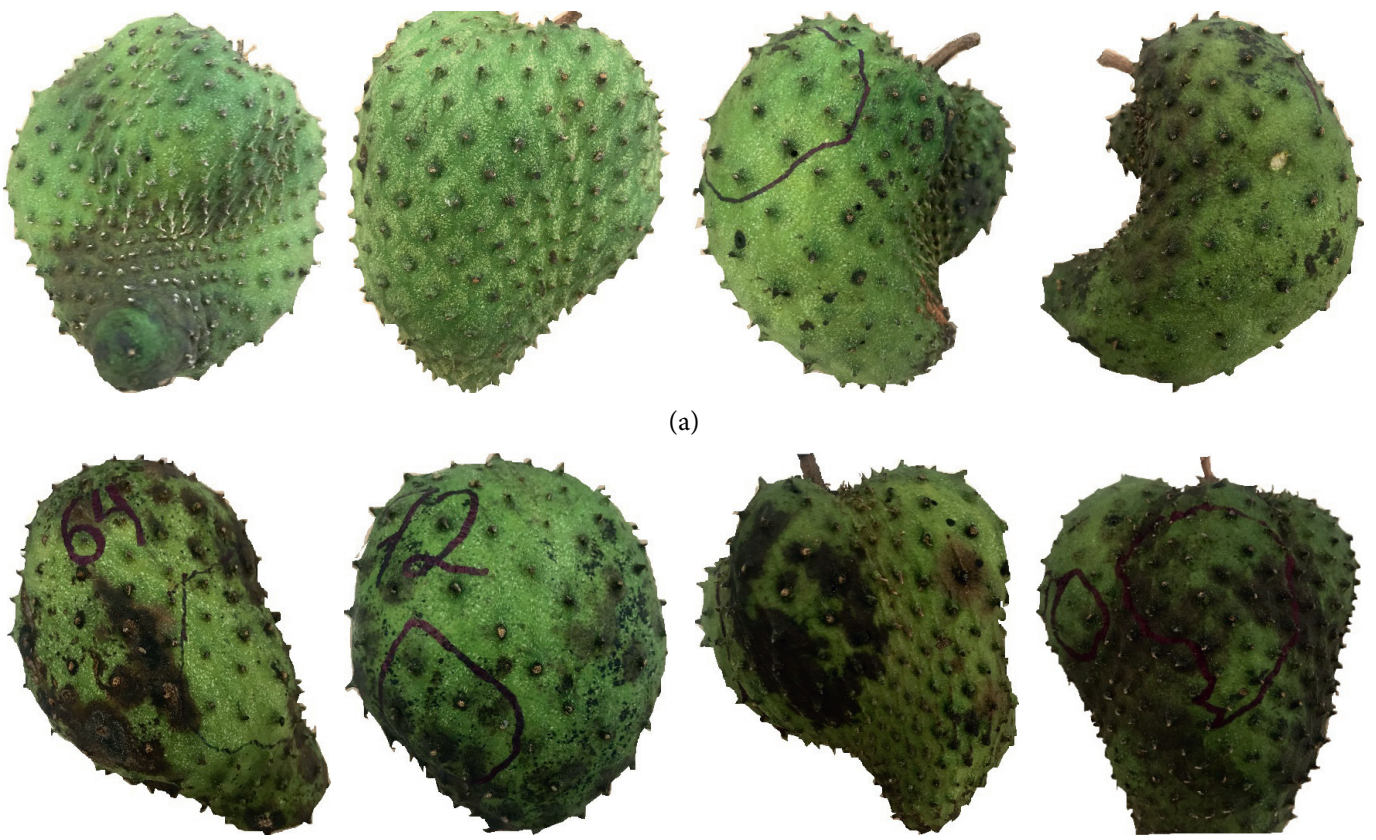

(a)
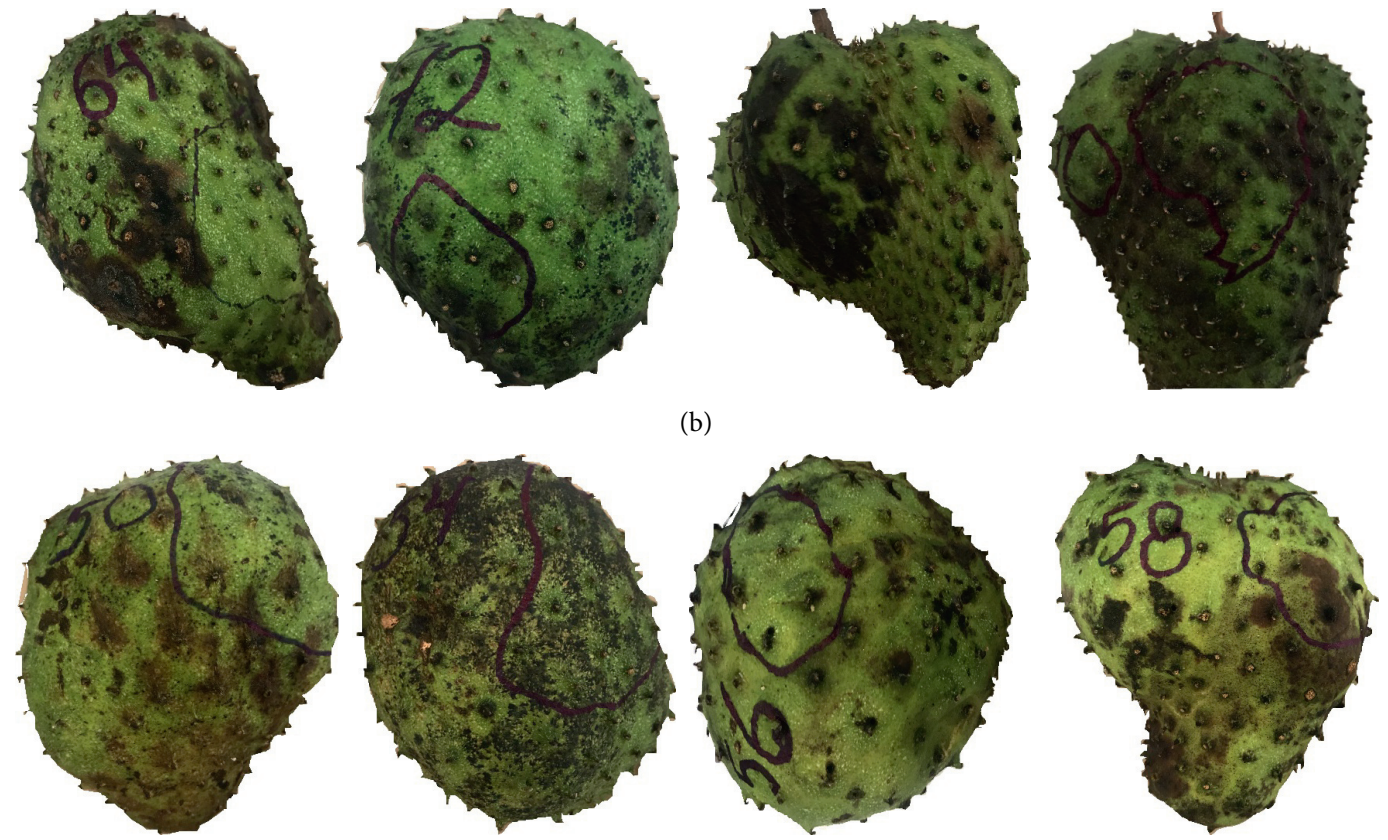

(c)

Figure 1: Soursop fruits stored for three days at $28 \pm 2^{\circ} \mathrm{C}$ and $95 \% \mathrm{RH}$. Control fruits (a) and fruits treated with C. siamense (b) and C. gloeosporioides (c).

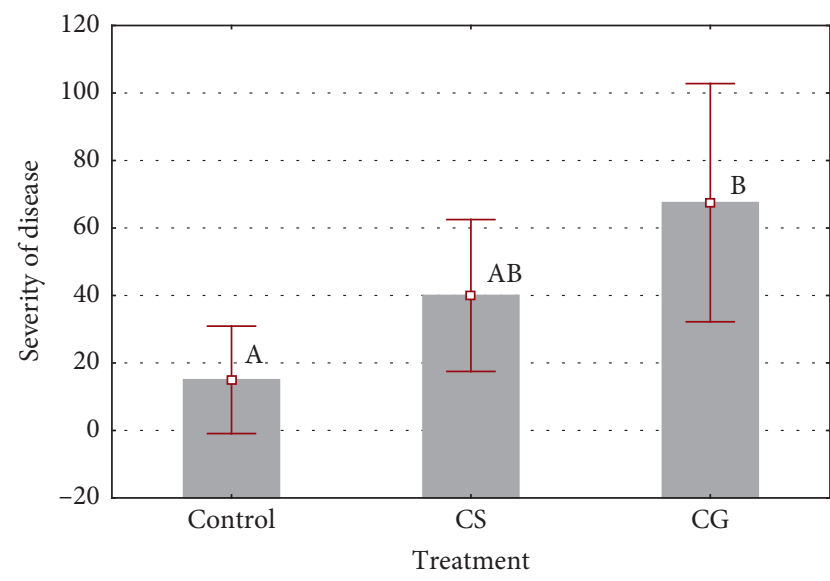

FIGURE 2: Infection severity of control fruits and fruits treated with Colletotrichum siamense (CS) and Colletotrichum gloeosporioides (CG).

fruits treated with either C. siamense or C. gloeosporioides showed a late response at day five of storage.
Balois-Morales et al. [15] mentioned that when abiotic factors stress the vegetative tissues, exists an accumulation of phenolic compounds. The high values obtained in this investigation indicate that the increase in the concentration of phenols is a response to stress, which can be abiotic or biotic [33], in this work by the presence of the pathogens. That involves the production of biochemical inhibitors (phenolic compounds) for the damage caused by pathogens in soursop fruits. Kim et al. [34] mentioned that phenols content could be associated with the infection process of the pathogen and the characteristics of defense materials such as phytoanthropin.

The increase in the concentration of phenolic compounds in soursop fruits can cause cell shrinkage, integrity loss of cell wall and cell membrane and the inhibition of the activity of essential enzymes in the metabolism of pathogens [35].

(2) Total Flavonoids. A decrease in the concentration of flavonoids $(P<0.05)$ was observed in the fruits inoculated with $C$. siamense (11.24 mg RE/100 g FW) in comparison 
TABLE 1: Phytochemical compounds determined in the soursop fruit treatments.

\begin{tabular}{lccc}
\hline Compound & Fruits control & Fruits inoculated with C. gloeosporioides & Fruits inoculated with C. siamense \\
\hline Total phenols & + & + & + \\
Flavonoids & + & + & + \\
Anthraquinones & - & - & - \\
Coumarins & - & + & - \\
Steroids & + & + & + \\
Terpenoids & + & - & + \\
Alkaloids & - & + & - \\
Saponins & + & + & + \\
\hline
\end{tabular}

$(+)$, presence; (-), absence.

with the fruits treated with C. gloeosporioides (20.24 mg RE/ $100 \mathrm{~g} \mathrm{FW})$ and the control treatment at day one $(20.35 \mathrm{mg}$ $\mathrm{RE} / 100 \mathrm{~g} \mathrm{FW}$ ), which indicates an early response for the fruits treated with this pathogen.

On the other hand, the fruits treated with both pathogens showed a late response, increasing their concentration at day three compared to the control $(P<0.05)$. The fruits inoculated with $C$. siamense had a concentration of $16.77 \mathrm{mg} \mathrm{RE} /$ $100 \mathrm{~g} \mathrm{FW}$, while fruit treated with C. gloeosporioides had the highest level of flavonoids (17.18 mg RE/100 g FW). In contrast, the control fruits had the lowest value of flavonoids (13.21 mg RE/100 g FW) (Figure 3(b)).

Flavonoids belong to the phenolic compounds [36], so that they can be affected by the polyphenol oxidase enzyme and decrease in its concentration in the early stages of a fungal infection, such occurs with the total soluble phenolic compounds of the fruits inoculated with $C$. siamense.

Defense and pigmentation are some of flavonoids functions [36]. The antioxidant activity of flavonoids results from a combination of its chelating properties of iron and retention of reactive oxygen species (ROS). Besides the inhibition of some enzymes such as lipoxygenase, cyclooxygenase, myeloperoxidase, and NADPH oxidase [37]. These activities provide them bactericidal, fungicidal, and antiviral properties [38]. For this reason, the increase in flavonoid concentrations may be a response to the presence of the pathogens on day 3 .

(3) Total Phytosterols. On day one of storage, no significant differences between treatments $(P>0.05)$ were found. However, a late response to pathogenesis was observed on day three due to the increase in the concentration of phytosterols in the treatments with both pathogens. The fruits inoculated with $C$. siamense showed the highest concentration (1155.11 mg EC/100 g FW), followed by the fruits inoculated with C. gloeosporioides (882.84 mg EC/100 g FW), in comparison to the control fruits $(18.45 \mathrm{mg} \mathrm{EC} / 100 \mathrm{~g} \mathrm{FW})$ (Figure 3(c)).

One of the defense mechanisms against biotic or abiotic stress of the plant is the production of phytosterols, which act as molecular signals within the plant or between the plant and its environment (environmental conditions or presence of microorganisms) [39]. Steroids are widely distributed in plants and function as signal molecules involved in processes such as stem elongation, vascular differentiation, male fertility, senescence and flowering time, leaf development, and resistance to biotic and abiotic stress [40].

Likewise, Burčová et al. [41] found that a Norway spruce bark hexanoic extract, whose main components were $\beta$-sitosterol, $\gamma$-sitosterol, and kampesterol, was able to inhibit the development of filamentous fungi such as Alternaria alternata, Mucor racemosus, Penicillium purpurogenum, and Rhizopus oryzae. Besides, Briceño et al. [42] found that suspension-cultured cells of Solanum lycopersicum cv. Micro-Tom was able to accumulate extracellularly isofucosterol and $\beta$-sitosterol as response to methyl jasmonate, which induces resistance in plants. These authors also found the same phenomenon with the application of cyclodextrins as potential elicitors of the defense response induction.

Therefore, the fruits inoculated with the pathogens showed a delayed response due to the synthesis of secondary metabolites related to plant defense, such as phytosterols and/or their precursors.

(3) Total Saponins. An early response was observed in pathogens treatments where the concentration of saponins for both treatments increased $(P<0.05)$, highlighting the fruits inoculated with $C$. siamense, with a concentration of $1612.12 \mathrm{mg}$ ESQS/100 g FW followed by the fruits inoculated with C. gloeosporioides (1049.90 mg ESQS/100 g FW) compared to the control treatment at day one, which had a concentration of $470.10 \mathrm{mg}$ ESQS/100 g FW.

Regarding the late response, it was observed that the treatments with the pathogens decreased the concentration of saponins ( $463.00 \pm 80 \mathrm{mg}$ ESQS/100 $\mathrm{g} \mathrm{FW}$ ) on day three of storage compared to the control, which increased its concentration to $1522.14 \mathrm{mg}$ ESQS/100 g FW (Figure 3(d)).

Apaza et al. [43] declared that plant species present defense mechanisms against pathogens such as fungi, bacteria, viruses, and nematodes. Among these mechanisms is the production of saponins, due to these acts as a biofungicide.

The ability to form complexes with sterols, proteins, and membrane phospholipids represents the primary mechanism of antifungal activity of saponins [44]. The saponins are within the constitutive defenses of the plants, which represent a chemical barrier [45]. The above could explain the reason for the early response in the soursop fruits inoculated with the pathogens. 


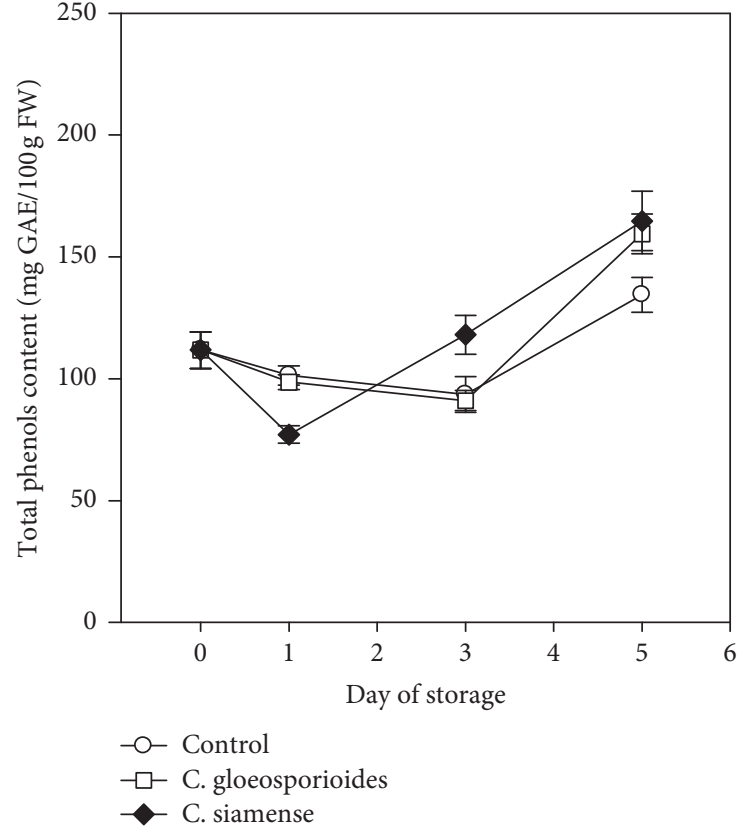

(a)

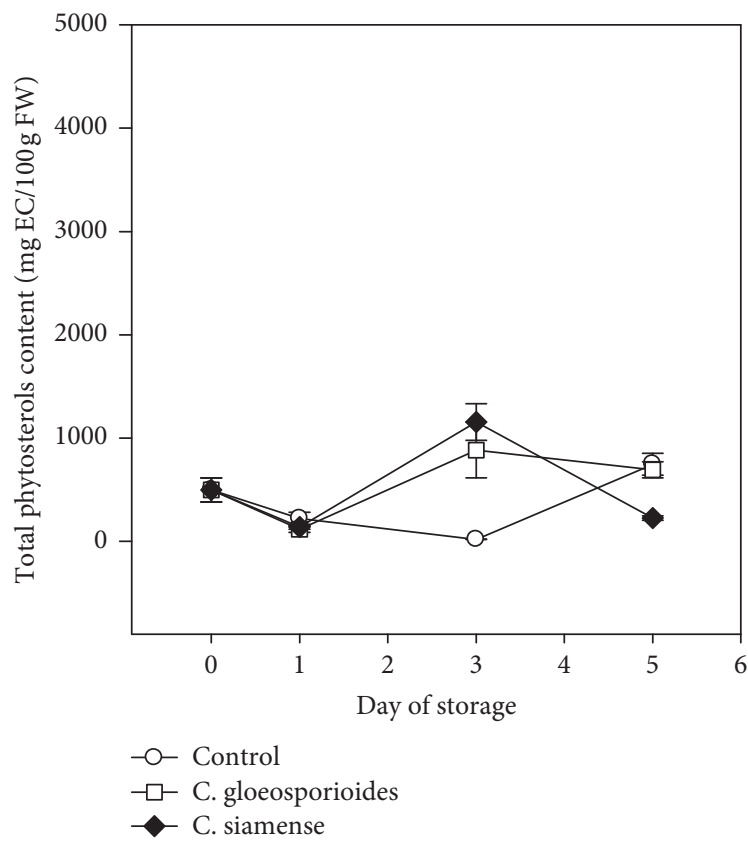

(c)

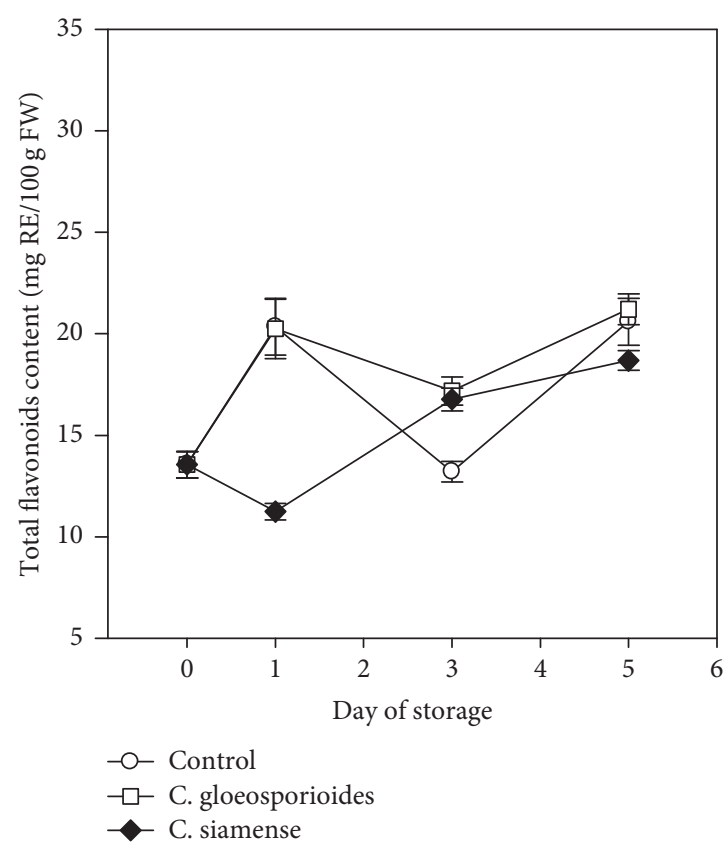

(b)

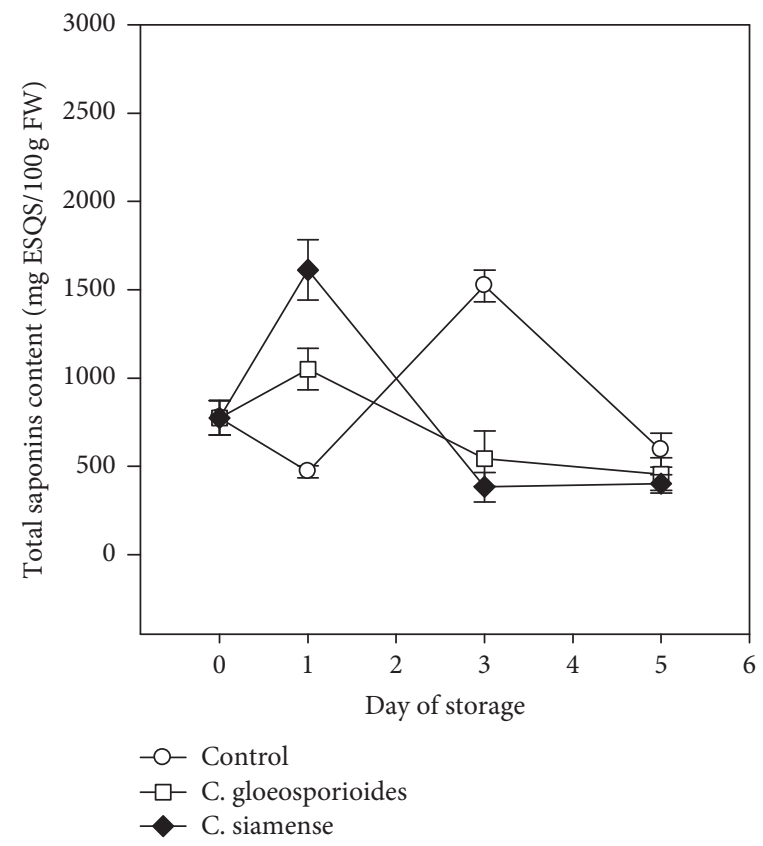

(d)

FIgURe 3: Total soluble phenols (a), total flavonoids (b), total phytosterols (c), and total saponins (d) content in soursop fruits with three different treatments. Control (C), C. gloeosporioides, and C. siamense.

Likewise, the use of saponins to form complexes with other molecules as response to pathogen attack could decrease their concentration in the fruit regarding control on day 3.

\section{Antioxidant activity: DPPH•, ABTS $\bullet+$, and FRAP}

The results of this investigation showed an early response in the fruits inoculated with $C$. siamense, increasing its antiradical activity DPPH• up to $194.09 \mathrm{mg}$
EAA/100 g FW $(P<0.05)$, while in the treatment with C. gloeosporioides, a value of $164.68 \mathrm{mg}$ EAA/100 g FW was obtained. However, they showed no significant differences compared to the control treatment at day one $(P>0.5)$, in which an antiradical activity of $174.45 \mathrm{mg}$ EAA/100 g FW was recorded.

In contrast, all the treatments increased their antiradical activity on day three and kept on day 5 , showing no significant differences between the treatments $(P>0.05)$ (Figure $4(\mathrm{a})$ ). 


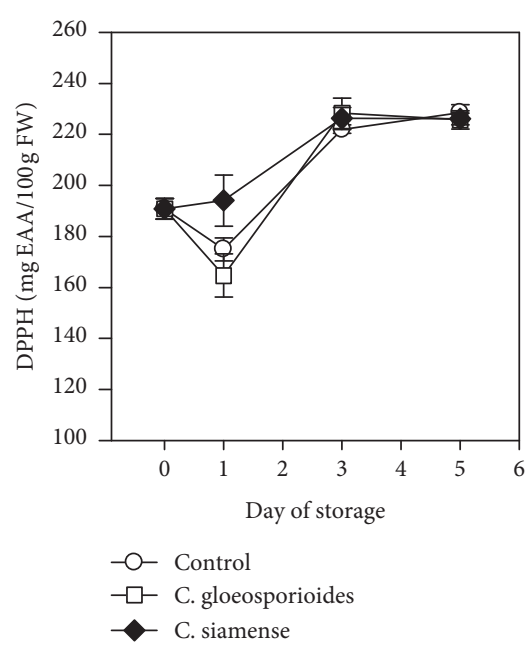

(a)

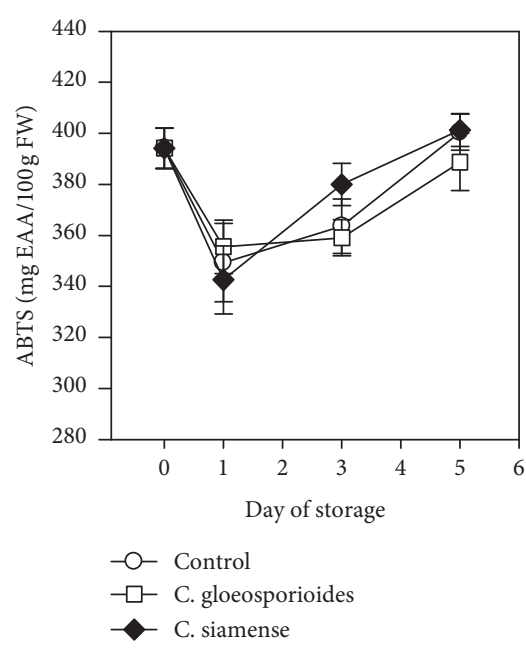

(b)

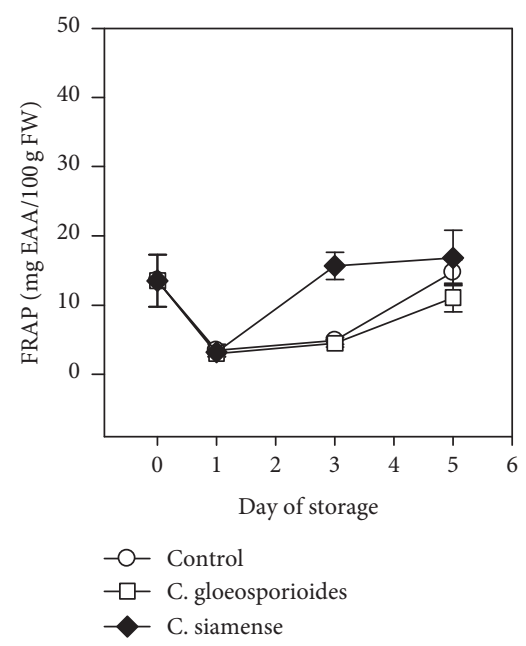

(c)

FIGURE 4: Antioxidant activity by the DPPH method• (a), antioxidant activity by the ABTS $\bullet+(\mathrm{b})$, and antioxidant activity by the FRAP method (c) in soursop fruits with three different treatments. Control (C), C. gloeosporioides, and C. siamense.

The DPPH method can trap the DPPH radical. The increase in this specific activity is given by the rise in the concentration of phenolic compounds on the third and fifth day of storage in all treatments. This increase in antioxidant activity in the soursop fruits could be related to the rise of phenolic compounds because they can neutralize free radicals by the presence and action of hydroxyl groups of phenolic compounds [46].

Our results coincide with those reported by BaloisMorales et al. [47] who reported an increase in antiradical activity ranging from 86.86 to $67.35 \mathrm{mg}$ EAA/ $100 \mathrm{~g} \mathrm{FW}$ in soursop fruits after four days of storage at room temperature. Thus, we can conclude that the increase in antiradical activity at the third and fifth day occurs as part of the healthy metabolism of the soursop fruits.

The soursop fruits inoculated with both pathogens did not show significant differences $(P>0.05)$ in antioxidant activity evaluated by ABTS $\bullet+$ concerning control at day 1 . The fruits showed an increase in their antioxidant activity at day three of storage where their maximum activity was up to date five with a value of $388.70 \pm 12 \mathrm{mg}$ EAA/100 g FW for both pathogens and $371.34 \pm 24.65 \mathrm{mg}$ EAA/100 $\mathrm{g} \mathrm{FW}$ for control (Figure 4(b)).

The increase of antioxidant activity on the ABTS $\bullet+$ radical in the ripening period can be due to the high metabolic activity characteristic of maturation and the climacteric period, besides to the action of ascorbic acid, which has a high concentration in the days after the harvest [48].

The results obtained in this study agree with those reported by Balois-Morales et al. [47] who said the antioxidant activity of $77.07-86.28 \mathrm{mg}$ EAA/100 g FW in soursop fruits since day 0 to after four days exposed to a temperature of $22^{\circ} \mathrm{C}$.

The fruits inoculated with $C$. siamense showed a late response on day three of storage in antioxidant reducing activity evaluated by FRAP, since they increased their antioxidant activity (16.81 mg EAA/100 g FW) compared to the control (4.84 mg EAA/100 g FW) (Figure 4(c)). The above is an essential mechanism of plant defense since plants trap iron as a strategy to reduce pathogen virulence; also, they may use the iron to increase local oxidative stress in defense responses against pathogens [49].

The changes in antioxidant activity (ABTS•+, DPPH•, and FRAP) are related to the high metabolic activity of the maturation process, besides the action of ascorbic acid, which has a high concentration days after harvest, together with the increase in phenolic compounds [48]. Soursop fruits showed antioxidant activity by this principle, coinciding with other investigations reported with the FRAP method in soursop fruits [50]. However, the pathogens may alter this behavior as observed in the present work with fruits treated with $C$. siamense.

The antioxidant activity DPPH• and FRAP of the soursop fruits inoculated with the pathogens allowed to see a marked difference concerning the control fruits. Liu et al. [51] showed that the high antioxidant capacity of soursop fruits is due to the high polyphenols content, which blocks oxidation and activates other antioxidants.

The increase of antioxidant activity may be related to the secondary responses of soursop fruits to defend against an infective process, which includes an elevation of the levels of constitutive defensive toxins, of pathogen receptors and structural reinforcement of cell walls in tissues. The process determines a substantial change in the metabolic profile of the active cells [52].

The marked responses in the fruits inoculated with C. siamense (early and late response) in comparison with those inoculated with C. gloeosporioides and the control fruits, whether in phytochemicals or antioxidant activity, might be related to the fact that the soursop presents higher resistance to the attack of $C$. siamense, so that its response mechanism is more sensitive.

At day 5, when fruits are senescent, there are no statistical differences among treatments $(P>0.05)$ in 
TABLE 2: Identification of soluble phenols in soursop by UPLC-ESI-QTOF MS ${ }^{\mathrm{E}}$.

\begin{tabular}{|c|c|c|c|c|c|c|c|}
\hline No. & Compound name & $\begin{array}{l}\text { Retention time } \\
\text { (min) }\end{array}$ & $\begin{array}{l}\text { Molecular } \\
\text { formula }\end{array}$ & $\begin{array}{l}\text { Expected mass } \\
(\mathrm{Da})\end{array}$ & $\begin{array}{l}\text { Observed mass } \\
\text { (Da) }\end{array}$ & $\begin{array}{c}\text { Mass error } \\
(\mathrm{ppm})\end{array}$ & Adduct \\
\hline 1 & p-Coumaric acid & 5.18 & $\mathrm{C}_{9} \mathrm{H}_{8} \mathrm{O}_{3}$ & 164.05 & 164.05 & -2.24 & $\begin{array}{l}{[\mathrm{M}-} \\
\mathrm{H}]^{-}\end{array}$ \\
\hline 2 & Ferulic acid & 5.71 & $\mathrm{C}_{10} \mathrm{H}_{10} \mathrm{O}_{4}$ & 194.06 & 194.06 & -2.24 & $\begin{array}{l}{[\mathrm{M}-} \\
\mathrm{H}]^{-}\end{array}$ \\
\hline 3 & $\begin{array}{l}\text { Quercetin 3-O- } \\
\text { glucoside }\end{array}$ & 5.84 & $\mathrm{C}_{21} \mathrm{H}_{20} \mathrm{O}_{12}$ & 464.10 & 464.10 & 0.42 & $\begin{array}{l}{[\mathrm{M}-} \\
\mathrm{H}]^{-}\end{array}$ \\
\hline 4 & Kaempferol & 5.89 & $\mathrm{C}_{15} \mathrm{H}_{10} \mathrm{O}_{6}$ & 286.05 & 286.25 & -5.05 & $\begin{array}{l}{[\mathrm{M}-} \\
\mathrm{H}]^{-}\end{array}$ \\
\hline 5 & $\begin{array}{l}\text { Kaempferol 3-O- } \\
\text { rutinoside }\end{array}$ & 6.22 & $\mathrm{C}_{27} \mathrm{H}_{30} \mathrm{O}_{15}$ & 594.16 & 594.16 & -0.20 & $\begin{array}{l}{[\mathrm{M}-} \\
\mathrm{H}]^{-}\end{array}$ \\
\hline 6 & Quercetin & 7.87 & $\mathrm{C}_{15} \mathrm{H}_{10} \mathrm{O}_{7}$ & 302.05 & 302.04 & -2.03 & $\begin{array}{l}{[\mathrm{M}-} \\
\mathrm{H}]^{-}\end{array}$ \\
\hline
\end{tabular}

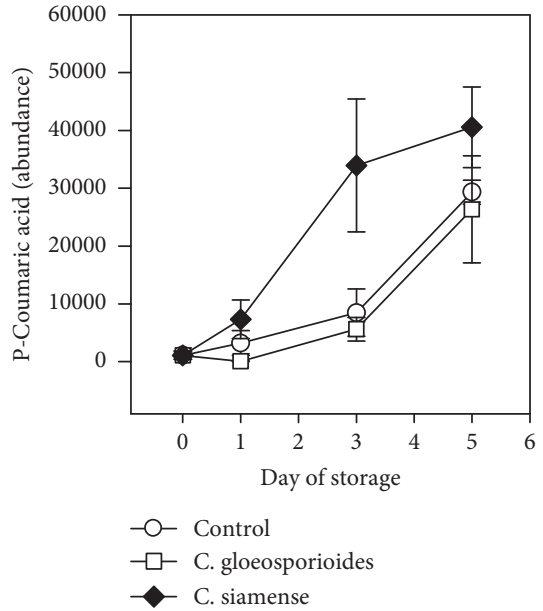

(a)

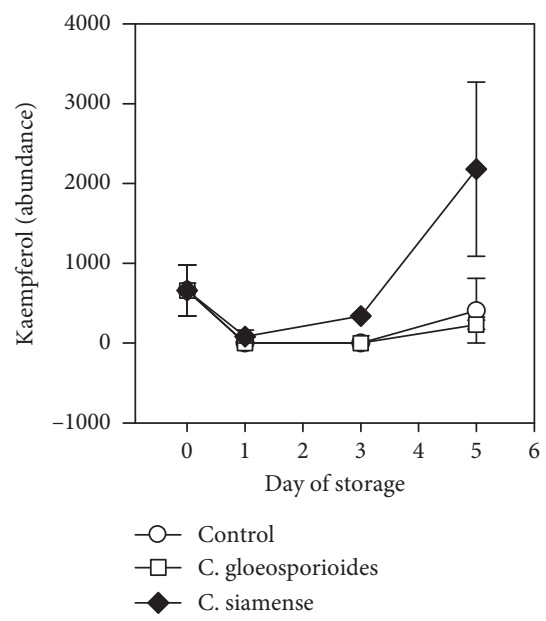

(d)

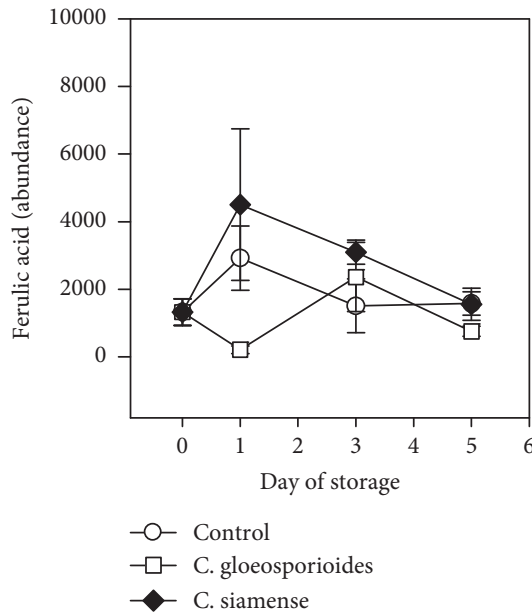

(b)
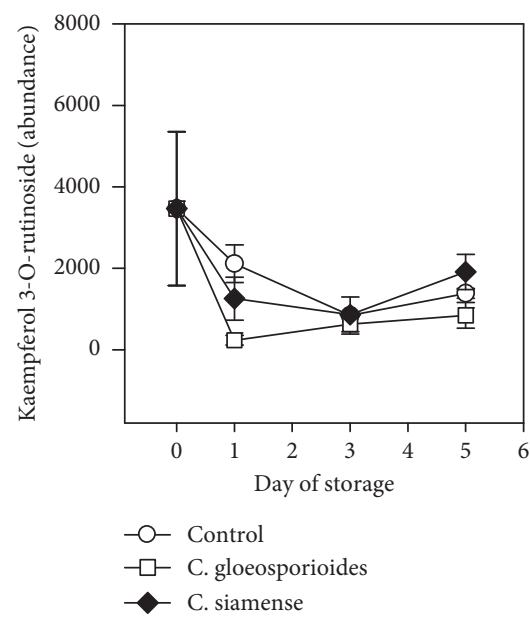

(e)

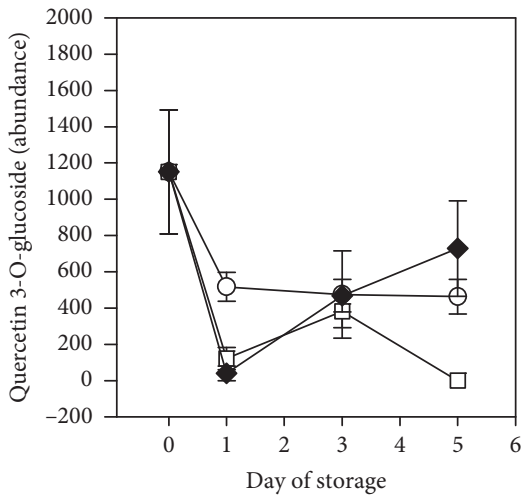

$-\mathrm{O}$ Control
$-\square$ C. gloeosporioides
- C. siamense

(c)

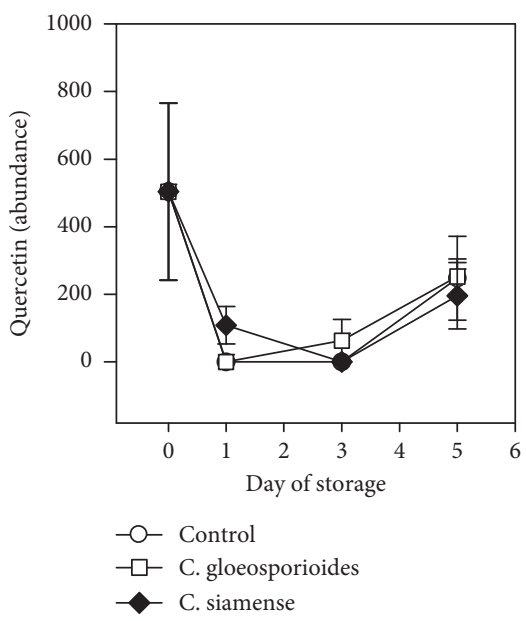

(f)

Figure 5: p-Coumaric acid (a), ferulic acid (b), quercetin 3-O-glucoside (c), kaempferol (d), kaempferol 3-O-rutinoside (e), and quercetin (f) abundance in soursop fruits with three different treatments during storage. Control (C), C. gloeosporioides, and C. siamense.

antioxidant activity (ABTS $\bullet+$, DPPH $\bullet$, and FRAP). Arauz [28] mentioned that the infection of climacteric fruits by C. gloeosporioides is an adaptation example of the pathogen to the host physiology, and the infection seems to be a case of coevolution, presenting an advantage, on the one hand, for the nutrition of the pathogen, and on the other hand, for the propagation of the fruit seeds. 
3.2.3. Identification and Dynamics of the Soluble Phenolic Compounds. Table 2 shows the identification of the main soluble phenols found in soursop. Two phenolic acids (ferulic and p-coumaric acids) and four flavonoids, specifically flavonols (kaempferol, kaempferol 3-O-rutinoside, quercetin, and quercetin 3-O-glucoside), were found in the soursop samples. These phenolic compounds have been found previously in soursop [53, 54]. Besides, these compounds have been reported for their antifungal activity [55].

Figure 5 shows the dynamic of the soluble phenol compounds identified. We observed an early response on day one. The level of quercetin was increasing in fruits treated with $C$. siamense, while the concentration of kaempferol 3-O-rutinoside and ferulic acid decreases in the fruits treated with C. gloeosporioides and quercetin 3-Oglucoside for fruits treated by both fungi regarding control fruits $(P<0.05)$.

Besides the above, a late response on day three was recorded, increasing the levels of p-coumaric acid and kaempferol in fruits treated with $C$. siamense regarding control fruits $(P<0.05)$. However, the level of quercetin 3O-glucoside decreased in fruits treated with C. gloeosporioides at day five $(P<0.05)$.

The induction of the quercetin production on day one indicates recognition of $C$. siamense by the fruits and the activation of its defense mechanism. Wilkinson et al. [56] mention that the first inducible defenses are faster and stronger against pathogen attack, which could be related to the low virulence of $C$. siamense against soursop fruit. Quercetin has been reported as a compound with antifungal activity [57], and it is produced as a strategy of plant defense against phytopathogenic fungi [58]. Likewise, quercetin can cause severe damage to fungi as Penicillium expansum, and this compound can increase defense proteins in the plants [57].

On the other hand, the metabolism changes on day three. Fruits change the response metabolites regarding day one, increasing the production of p-coumaric acid and kaempferol in fruits treated with $C$. siamense. These changes could be related either to the use of a more cost-efficient mechanism [56] or to an adaptation of fungi metabolism to plant defense, since the fungi can change from a biotrophic to a necrotrophic metabolism [59].

In another way, even though kaempferol 3-O-rutinoside, quercetin 3-O-glucoside, and ferulic acid have been reported with fungicide activity [58], these compounds decreased their levels regarding control on day one and quercetin 3-O-glucoside on day five in fruits treated with C. gloeosporioides. Likewise, quercetin 3-Oglucoside decreased in fruits treated with $C$. siamense on day one. The above could be due to the production of effectors by fungi. Van der Dous and Rep [60] mention that the fungi can secrete effectors, which are proteins that protect fungi from plant defense compounds or could suppress the host's immune system. So, these compounds can promote the colonization and proliferation of disease symptoms. The above could be related to a higher virulence of C. gloeosporioides and the appearance of more severe symptoms on fruits treated with this fungus.

\section{Conclusion}

Soursop fruits had a response to the attack of pathogens during ripening at the physicochemical and oxidative levels, which are associated with the production of compounds that, in high concentrations, inhibit the development of the pathogens. Both pathogens cause an early response in the fruit, increasing the concentration of saponins and decreasing the production of quercetin 3-O-glucoside. C. siamense decreased total soluble phenols and flavonoids and increased antiradical activity DPPH. C. gloeosporioides decreased the levels of kaempferol 3-O-rutoside and ferulic acid. On the other hand, both pathogens cause a late response in soursop fruits decreasing the concentration of saponins and increasing flavonoids and phytosterols. C. siamense increased total soluble phenols, p-coumaric acid, kaempferol, and antiradical activity FRAP. Also, C. gloeosporioides decreased the production of quercetin 3$\mathrm{O}$-glucoside. As well as, pathogens could produce compounds that inhibit the production of defense compounds by fruits, which could be related to an increase of disease severity. The soursop fruits showed higher sensitivity to the attack of C. siamense, which could be related to higher resistance to the attack of this pathogen compared to C. gloeosporioides.

\section{Data Availability}

The data used to support the findings of this study are available from the corresponding author upon request.

\section{Conflicts of Interest}

The authors declare that there are no conflicts of interest regarding the publication of this article.

\section{Acknowledgments}

The authors would like to thank SAGARPA-CONACyT for the financial support through the project "Aprovechamiento de germoplasma, desarrollo tecnológico e innovación en cadenas de valor de anonáceas en México" (number: 266891) and CONACYT for the Ph.D. scholarship granted to Alejandro Rubio Melgarejo (585312).

They also thank Dra. Iza Fernanda Pérez-Ramírez for her collaboration in the identification of soluble phenolic compounds.

\section{References}

[1] L. M. A. De Coelho and R. E. Alves, "Soursop (annona muricata L.),"'Soursop (annona muricata L.)," in Postharvest Biology and Technology of Tropical and Subtropical Fruits. Mangosteen to White Sapote., M. E. Yahia, Ed., vol. 4, Woodhead Publishing Limited, Oxford/Philadelphia, pp. 363-391, Woodhead Publishing Limited, 2011.

[2] Servicio de Información Agroalimentaria y Pesquera (SIAP), 2019, http://infosiap.siap.gob.mx/aagricola_siap_gb/ientidad/ index.jsp.

[3] G. Ojeda, J. Coronado, R. Nava, B. Sulbarán, D. Araujo, and L. Cabrera, "Caracterización fisicoquímica de la pulpa de la 
guanábana (Annona muricata) cultivada en el occidente de venezuela," Boletín del Centro de Investigaciones Biológicas, vol. 41, pp. 151-160, 2007.

[4] J. O. Jiménez-Zurita, R. Balois-Morales, I. Alia-Tejacal et al., "Cold storage of two selections of soursop (annona muricataL.) in Nayarit, Mexico," Journal of Food Quality, vol. 2017, Article ID 4517469, 9 pages, 2017.

[5] G. Berumen-Varela, M. A. Hernández-Oñate, and M. E. Tiznado-Hernández, "Utilization of biotechnological tools in soursop (Annona muricata L.)," Scientia Horticulturae, vol. 245, pp. 269-273, 2019.

[6] Y. C. Han, X. G. Zeng, F. Y. Xiang, L. Ren, F. Y. Chen, and Y. C. Gu, "Distribution and characteristics of Colletotrichum spp. associated with anthracnose of strawberry in Hubei, China," Plant Disease, vol. 100, no. 5, pp. 996-1006, 2016.

[7] E. Álvarez, L. Gañán, A. Rojas-Triviño, J. F. Mejía, G. A. Llano, and A. González, "Diversity and pathogenicity of Colletotrichum species isolated from soursop in Colombia," European Journal of Plant Pathology, vol. 139, no. 2, pp. 325-338, 2014.

[8] J. Nawrocka and U. Małolepsza, "Diversity in plant systemic resistance induced by Trichoderma," Biological Control, vol. 67, no. 2, pp. 149-156, 2013.

[9] C. M. J. Pieterse, D. Van der Does, C. Zamioudis, A. LeonReyes, and S. C. M. Van Wees, "Hormonal modulation of plant immunity," Annual Review of Cell and Developmental Biology, vol. 28, no. 1, pp. 489-521, 2012.

[10] W. Zárate-Martínez, S. González-Morales, F. Ramírez-Godina, A. Robledo-Olivo, and A. Juárez-Maldonado, "Efecto de los ácidos fenólicos en plantas de tomate (Lycopersicon esculentum Mill.) inoculadas con Clavibacter michiganensis," Revista mexicana de ciencias agrícolas, vol. 9, pp. 4367-4379, 2018.

[11] E. H. Neilson, J. Q. D. Goodger, I. E. Woodrow, and B. L. Møller, "Plant chemical defense: at what cost?" Trends in Plant Science, vol. 18, no. 5, pp. 250-258, 2013.

[12] D. H. Díaz-Montenegro, "Morfología y clasificación de flores y frutos," in Fisiología de Árboles Frutalesp. 227, Universidad Autónoma de Nayarit, Nayarit, MX, USA, 2002.

[13] P. U. Bautista-Rosales, M. Calderón-Santoyo, R. Servín-Villegas, N. A. Ochoa-Álvarez, and J. A. Ragazzo-Sánchez, "Action mechanisms of the yeast Meyerozyma caribbica for the control of the phytopathogen Colletotrichum gloeosporioides in mangoes," Biological Control, vol. 65, no. 3, pp. 293-301, 2013.

[14] J. M. Benbow and D. Sugar, "Fruit surface colonization and biological control of postharvest diseases of pear by preharvest yeast applications," Plant Disease, vol. 83, no. 9, pp. 839-844, 1999.

[15] R. Balois-Morales, M. T. Colinas-León, M. T. Colinas-León, C. B. Peña-Valdivia, S. H. Chávez-Franco, and I. Alia-Tejacal, "Sistema de estrés oxidativo, fenoles-polifenol oxidasa-peroxidasa, de frutos de pitahaya (Hylocereus undatus) almacenados con frío," Revista Chapingo Serie Horticultura, vol. XIII, no. 2, pp. 115-120, 2007.

[16] A. Sofowora, Medicinal Plants and Traditional Medicine in Africa, John Wiley and Sons LTD, Ife, Nigeria, second edition, 1993.

[17] J. B. Harborne, Phytochemical Methods. A Guide to Modern Techniques of Plant Analysis, CapmaN y Hall, London, UK, Third edition, 1998.

[18] W. C. Evans, Trease and Evans Pharmacognosy, Elsevier Health Sciences, Nev York, NY, USA, 16th edition, 2009.
[19] V. L. Singleton, R. Orthofer, and R. M. Lamuela-Raventós, "Analysis of total phenols and other oxidation substrates and antioxidants by means of folin-ciocalteu reagent," Oxidants and Antioxidants Part A, vol. 299, pp. 152-178, 1999.

[20] Z. Maksimović, D. Malencić, and N. Kovacević, "Polyphenol contents and antioxidant activity of Maydis stigma extracts," Bioresource Technology, vol. 96, no. 8, pp. 873-877, 2005.

[21] G. C. E. Lobato, R. A. Gómez, C. M. D. J. Alor, M. J. Badal, V. C. Hernández, and O. V. C. Díaz, "Cuantificación de flavonoides, taninos y esteroides en plantas medicinales de uso tradicional en Tabasco," Semana de Divulgación y Video Científico, pp. 76-79, University d Autonomous Juárez of Tabasco, Tabasco, MX, USA, 2008.

[22] R. H. Soto, E. C. Lugo, L. Díaz, and S. Villanueva, "Extracción y cuantificación indirecta de las saponinas de "Agave lechuguilla"” Torrey. E-Gnosis, vol. 3, pp. 1-9, 2005.

[23] G. L. Miller, "Use of dinitrosalicylic acid reagent for determination of reducing sugar," Analytical Chemistry, vol. 31, no. 3, pp. 426-428, 1959.

[24] W. Brand-Williams, M. E. Cuvelier, and C. Berset, "Use of a free radical method to evaluate antioxidant activity," $L W T$ Food Science and Technology, vol. 28, no. 1, pp. 25-30, 1995.

[25] R. Re, N. Pellegrini, A. Proteggente, A. Pannala, M. Yang, and C. Rice-Evans, "Antioxidant activity applying an improved ABTS radical cation decolorization assay," Free Radical Biology and Medicine, vol. 26, no. 9-10, pp. 1231-1237, 1999.

[26] G.-C. Yen and H.-Y. Chen, "Antioxidant activity of various tea extracts in relation to their antimutagenicity," Journal of Agricultural and Food Chemistry, vol. 43, no. 1, pp. 27-32, 1995.

[27] S. Rodríguez-González, I. M. Gutiérrez-Ruíz, I. F. PérezRamírez, O. Mora, M. Ramos-Gomez, and R. ReynosoCamacho, "Mechanisms related to the anti-diabetic properties of mango (Mangifera indica L.) juice by-product," Journal of Functional Foods, vol. 37, pp. 190-199, 2017.

[28] L. F. Arauz, "Mango anthracnose: economic impact and current options for integrated managaement," Plant Disease, vol. 84, no. 6, pp. 600-611, 2000.

[29] V. Montero-Tavera, J. L. Morales-García, M. M. GonzálezChavira, J. L. Anaya-López, T. Corona-Torres, and A. GálvezMariscal, "Genetic, pathogenic and morphological diversity of fungi Colletotrichum gloeosporioides (Penz.) from Michoacan, Mexico," Revista Mexicana de Ciencias Agrícolas, vol. 1, pp. 159-174, 2010.

[30] S. A. Vergara, C. K. Páucar, C. C. Morales, M. O. Castro, S. P. Pizarro, and R. J. Díaz, "Obtención de extractos de hojas de Annona muricata L. (Guanábana) inducidos por su efecto inhibidor de la corrosión," Revista de la Sociedad Química del Perú, vol. 84, pp. 119-132, 2018.

[31] P. Wikaningtyas and E. Y. Sukandar, "The antibacterial activity of selected plants towards resistant bacteria isolated from clinical specimens," Asian Pacific Journal of Tropical Biomedicine, vol. 6, no. 1, pp. 16-19, 2016.

[32] A. Pérez-Márquez, Y. Vidal-Aguiar, and T. Mulkay-Vitón, "Contenido de Fenoles Totales en frutos de mango 'Super Haden' dañados por antracnosis y tratados en poscosecha," Cultivos Tropicales, vol. 37, pp. 71-77, 2016.

[33] M. S. C. Pedras, E. E. Yaya, and E. Glawischnig, "The phytoalexins from cultivated and wild crucifers: chemistry and biology," Natural Product Reports, vol. 28, no. 8, pp. 1381-1405, 2011.

[34] H. G. Kim, G.-S. Kim, J. H. Lee et al., "Determination of the change of flavonoid components as the defence materials of Citrus unshiu Marc. fruit peel against Penicillium digitatum by 
liquid chromatography coupled with tandem mass spectrometry," Food Chemistry, vol. 128, no. 1, pp. 49-54, 2011.

[35] M. Benli, N. Yiğit, F. Geven, K. Güney, and Ü. Bingöl, "Antimicrobial activity of endemicCrataegus tanacetifolia (Lam.) Pers and observation of the inhibition effect on bacterial cells," Cell Biochemistry and Function, vol. 26, no. 8, pp. 844-851, 2008.

[36] A. Á. García and E. P. U. Carril, "Metabolismo secundario de plantas," Reduca (biología), vol. 2, 2011.

[37] G. Garrido, M. Ortiz, and P. Pozo, "Fenoles y flavonoides totales y actividad antioxidante de extractos de hojas de Lampaya medicinalis F. Phil," Journal of Pharmacy and Pharmacognosy Research, vol. 1, pp. 30-38, 2013.

[38] A. Tabera, E. Bedascarrasbure, L. Maldonado, A. Alvarez, and A. Van Der Host, "Actividad antibacteriana de propóleos argentinos enfrentados a Staphylococcus aureus," in Actas del Congreso Internacional de Propóoleos, p. 97, Universidad de Santiago del Estero, Buenos Aires, Argentina, 2000.

[39] R. Akula and G. A. Ravishankar, "Influence of abiotic stress signals on secondary metabolites in plants," Plant Signaling \& Behavior, vol. 6, no. 11, pp. 1720-1731, 2011.

[40] V. Castilla, J. Ramírez, and C. E. Coto, "Prospectiva del uso de esteroides de plantas como antivirales," Química Viva, vol. 8, pp. 8-24, 2009.

[41] Z. Burčová, F. Kreps, M. Greifová et al., “Antibacterial and antifungal activity of phytosterols and methyl dehydroabietate of Norway spruce bark extracts," Journal of Biotechnology, vol. 282, pp. 18-24, 2018.

[42] Z. Briceño, L. Almagro, A. B. Sabater-Jara, A. A. Calderón, M. A. Pedreño, and M. A. Ferrer, "Enhancement of phytosterols, taraxasterol and induction of extracellular pathogenesis-related proteins in cell cultures of Solanum lycopersicum cv Micro-Tom elicited with cyclodextrins and methyl jasmonate," Journal of Plant Physiology, vol. 169, no. 11, pp. 1050-1058, 2012.

[43] R. Apaza, H. Smeltekop, Y. Flores, G. Almanza, and L. Salcedo, "Efecto de saponinas de Chenopodium quinoa Willd contra el fitopatógeno Cercospora beticola Sacc," Revista de protección vegetal, vol. 31, pp. 63-69, 2016.

[44] R. Montes-Belmont, "Diversidad de compuestos químicos producidos por las plantas contra hongos fitopatógenos," Revista mexicana de micología, vol. 29, pp. 73-82, 2009.

[45] L. Diaz, "Interacciones moleculares entre plantas y microrganismos: saponinas como defensas químicas de las plantas y su tolerancia a los microrganismos," Revista de Estudios Transdisciplinarios, vol. 1, pp. 32-55, 2009.

[46] S. F. Akomolafe and O. B. Ajayi, "A comparative study on antioxidant properties, proximate and mineral compositions of the peel and pulp of ripe Annona muricata (L.) fruit," International Food Research Journal, vol. 22, pp. 2381-2388, 2015.

[47] R. Balois-Morales, J. O. Jiménez-Zurita, I. Alia-Tejacal, G. G. López-Guzmán, Y. A. Palomino-Hermosillo, and L. M. Sánchez-Herrera, "Antioxidant enzymes and antioxidant activity in two soursop selections (Annona muricata L.) from Nayarit, Mexico stored at $15^{\circ} \mathrm{C}$," Revista Brasileira de Fruticultura, vol. 41, pp. 2-9, 2019.

[48] C. C. J. Márquez, L. V. Villacorta, B. D. P. Yepes, C. Velásquez, H. José, and V. J. R. Cartagena, "Physiological and physicochemical characterization of the soursop fruit (Annona muricata L. cv. Elita)," Revista Facultad Nacional de Agronomía Medellín, vol. 65, pp. 6477-6486, 2012.

[49] E. H. Verbon, P. L. Trapet, I. A. Stringlis, S. Kruijs, P. A. H. M. Bakker, and C. M. J. Pieterse, "Iron and immunity," Annual Review of Phytopathology, vol. 55, no. 1, pp. 355-375, 2017.

[50] J. Rodríguez, O. Valdés, and O. Queris, “Actividad antioxidante de vinos elaborados con frutas tropicales," Ciencia $y$ Tecnología de Alimentos, vol. 17, pp. 66-68, 2007.

[51] P. Liu, H. Kallio, and B. Yang, "Phenolic compounds in hawthorn (Crataegus grayana) fruits and leaves and changes during fruit ripening," Journal of Agricultural and Food Chemistry, vol. 59, no. 20, pp. 11141-11149, 2011.

[52] J. M. Vivanco, E. Cosio, V. M. Loyola-Vargas, and H. E. Flores, "Mecanismos químicos de defensa en las plantas," Boletín Latinoamericano y del Caribe de Plantas Medicinales y Aromáticas, vol. 11, pp. 111-126, 2005.

[53] V. M. Jiménez, M. Gruschwitz, R. M. Schweiggert, R. Carle, and P. Esquivel, "Identification of phenolic compounds in soursop (Annona muricata) pulp by high-performance liquid chromatography with diode array and electrospray ionization mass spectrometric detection," Food Research International, vol. 65, pp. 42-46, 2014.

[54] P. Vit, B. Santiago, and E. M. Pérez-Pérez, "Composición química y actividad antioxidante de pulpa, hoja y semilla de guanábana Annona muricata," Interciencia, vol. 39, pp. 350353, 2014

[55] J. Yong-Sheng, "Recent advances in natural antifungal flavonoids and their derivates," Bioorganic \& Medicinal Chemistry Letters, vol. 29, Article ID 126589, 2019.

[56] S. W. Wilkinson, M. H. Magerøy, A. López Sánchez et al., "Surviving in a hostile world: plant strategies to resist pests and diseases," Annual Review of Phytopathology, vol. 57, no. 1, pp. 505-529, 2019.

[57] M. Zhang, L. Xu, L. Zhang, Y. Guo, X. Qi, and L. He, "Effects of quercetin on postharvest blue mold control in kiwifruit," Scientia Horticulturae, vol. 228, pp. 18-25, 2018.

[58] M. Mikulic-Petkovsek, V. Schmitzer, J. Jakopic et al., "Phenolic compounds as defence response of pepper fruits to Colletotrichum coccodes," Physiological and Molecular Plant Pathology, vol. 84, pp. 138-145, 2013.

[59] W. A. Vargas, J. M. S. Martín, G. E. Rech et al., "Plant defense mechanisms are activated during biotrophic and necrotrophic development of colletotricum graminicola in maize," Plant Physiology, vol. 158, no. 3, pp. 1342-1358, 2012.

[60] H. C. Van der Dous and M. Rep, "Adaptation to the host environment by plant-pathogenic fungi," Annual Review of Phytopathology, vol. 55, no. 1, pp. 427-450, 2017. 